\title{
Serum and tissue levels of insulin-like growth factor-I in women with dysplasia and HPV-positive cervical cancer
}

\author{
AGATA JOZEFIAK ${ }^{1}$, JOANNA PACHOLSKA-BOGALSKA ${ }^{2}$, MAGDALENA MYGA-NOWAK ${ }^{2}$, WITOLD KEDZIA ${ }^{1}$, \\ ANNA KWASNIEWSKA ${ }^{4}$, MICHAL LUCZAK ${ }^{3}$, HELENA KEDZIA ${ }^{1}$ and ANNA GOZDZICKA-JOZEFIAK ${ }^{2}$ \\ ${ }^{1}$ Division of Uterine Cervix Pathophysiology, University of Medical Sciences, ul. Polna 33, 60-535 Poznan; ${ }^{2}$ Department of \\ Molecular Virology, Adam Mickiewicz University, ul. Umultowska, 69, 61-614 Poznan; ${ }^{3}$ Department of Biochemistry \\ and Molecular Biology, University of Medical Sciences, Poznan, ul. Swiecickiego 6, 60-781 Poznan; ${ }^{4}$ Department of \\ Obstetrics and Gynecology, University School of Medicine of Lublin, ul. Staszica 16, 20-081 Lublin, Poland
}

Received November 15, 2007; Accepted December 27, 2007

\begin{abstract}
The ectocervical epithelium is the target of the oncogenic human papillomavirus (HPV), which acts as an etiological agent in the development of cervical carcinoma. However, the HPV-mediated transformation of human epithelial cells is a multi-step process dependant on unknown factors additional to the virus, which is a necessary but, in and of itself, insufficient catalyst. In the present study, we characterized the role of insulin-like growth factor-I (IGF-I) in this process. IGF-I is an endocrine hormone with an autocrine and paracrine role in many tissues. Our data demonstrated that autocrine secretion of IGF-I can contribute to HPV-induced carcinogenesis of the epithelium. An immunohistochemical study showed that IGF-I was present in the nuclei of the reproductive layer of the paraepidermal epithelium in $89 \%$ of cases of intraepithelial neoplasia (CIN I-III) and $60 \%$ of cases of invasive cervical cancer. The presence of IGF-I at a nuclear localization in the cells studied suggests that it may also have intranuclear actions.
\end{abstract}

\section{Introduction}

Human papillomaviruses (HPVs) have been established as the sexually transmitted agents responsible for most invasive cervical cancers. HPV16 is the most common type among cervical cancers, and also among cytologically-normal women. However, only 1-5\% of HPV-positive women develop cervical cancer. HPV-mediated transformation of human epithelial cells has been recognized as a multi-step process in which the virus is a necessary but, in and of itself, insufficient catalyst. The transformation must depend on additional unknown factors and (epi)genetic events.

Correspondence to: Professor Anna Gozdzicka-Jozefiak, Department of Molecular Virology, Adam Mickiewicz University of Poznan, ul. Umultowska 69, 61-614 Poznan, Poland

E-mail: agjozef@amu.edu.pl

Key words: insulin-like growth factor-I, cervical cancer, human papillomavirus
HPVs infect the epithelial cells and depend on epithelial differentiation for the completion of their life cycle (1). Insulin-like growth factor-I (IGF-I) is a peptide hormone with mitogenic and antiapoptotic properties involved in the regulation of proliferation and differentiation of many cell types, including normal and transformed epithelial cells. The human IGF-I gene is located within a region of over $85 \mathrm{~kb}$ on chromosome 12-12p22, and consists of at least 6 exons. Most of the IGF-I transcripts are initiated in exon 1, and a large mRNA precursor is alternatively spliced into two different classes of mRNA: IGF-IA and IGF-IB. IGF-IA is encoded by mRNAs derived by splicing exons 4 and 6 , and IGF-IB is encoded by mRNAs, including exons 4,5 and 6 (2-5). The action of IGF-I is mediated mainly through a specific cell membrane receptor, IGF-IR, and controlled by IGFBPs (mainly IGFBP-3) (6). The bulk of IGF-I and IGFBPs found in the blood are synthesized in the liver. However, tissue IGF-I bioactivity is not only a function of the circulating level of this peptide and its binding proteins, but also of local production of IGF-I and IGFBPs $(3,5)$. Recent prospective studies have provided evidence that elevated IGF-I levels are related to the risk of certain cancers, such as prostate, lung, breast and colon cancer (7-13), but little is known about the association of IGF-I with cervical cancer and its role in the regulation of cervical cancer development and progression $(14,15)$.

The aim of this study was the analysis of IGF-I and IGFBP-3 in the serum levels of women with normal cervix epithelium, cervical cancer, HPV-positive and HPV-negative dysplasia, as well as an association with tissue IGF-I expression determined by real-time PCR and immunohistochemical study.

\section{Materials and methods}

The study material included human tissue samples and blood serum. The study groups of patients are described in Tables I and II. In respect to the differentiation of the neoplastic cells, the following groups of patients were identified according to the WHO classification system: G1 $(n=11), G 2(n=16)$ and G3 $(n=15)$ (Table I). According to FIGO clinical staging, 8 patients were classified as stage 0 (carcinoma in situ), 13 as IA, 
Table I. Study groups and frequency of DNA HPV occurrence.

\begin{tabular}{lccc}
\hline Group & $\begin{array}{c}\text { No. of } \\
\text { cases }\end{array}$ & $\begin{array}{c}\text { HPV oncogenic } \\
\text { types 16/18 }\end{array}$ & $\begin{array}{c}\% \text { HPV } \\
\text { positive }\end{array}$ \\
\hline CIN I (L-SIL) & 8 & 6 & 75 \\
CIN II /III (H-SIL) & 26 & 21 & 80.78 \\
Squamous cell carcinoma & 36 & 35 & 97.22 \\
Adenocarcinoma & 6 & 6 & 100 \\
Control & 80 & 12 & 15 \\
\hline
\end{tabular}

21 as IB and 8 as IIA (Table II). The patients were between 24 and 72 years of age (mean 54.3). All patients underwent surgical procedures at the Departments of Oncological Gynecology and Gynecology of the Medical University of Lublin and at the Department of Gynecology of the Medical University of Poznan. The control group was comprised of normal tissue of the uterine cervix obtained from 80 patients, 40-72 years of age, who underwent surgical treatment for uterine myomas.

DNA isolation. Genomic DNA was isolated from tissue samples using the QIAamp DNA Mini Kit (Qiagen) according to the manufacturer's instructions.

$H P V$ analysis. Genomic DNA was used for amplification by PCR (polymerase chain reaction) with two specific primer pairs complementary to the HPV genome universal for 33 types of HPV viruses: MY09, 5'-CGTCCMARRGGAWAC TGATC-3' and MY11, 5'-GCMCAGGGWCATAAYAAT GG-3'; for HPV16-E7/16A, 5'-ATAATATAAGGGGTCGG TGG-3' and E7/16B 5'-CATTTTCGTTCTCGTCATCTG-3'; for HPV18-ME18A, 5'-CACGGCGACCCTACAAGCTAC CTG-3' and ME18B, 5'-TGCAGCACGAATTGGCACTGG CCTC-3'. PCR reactions were performed in a total volume of $20 \mu \mathrm{l}$. The final mixture contained $1 \mu \mathrm{M}$ primers, $200 \mu \mathrm{M}$ dNTPs, $1 \mathrm{X}$ PCR buffer $\left(10 \mathrm{mM}\right.$ Tris- $\mathrm{HCl}, \mathrm{pH} 8.8$ at $25^{\circ} \mathrm{C}$, $1.5 \mathrm{mM} \mathrm{MgCl}_{2}, 50 \mathrm{mM} \mathrm{KCl}, 0.1 \%$ Triton X-100) and $1 \mathrm{U} /$ $25 \mu 1$ mixture of Taq polymerase (Finnzyme). The samples were amplified for 35 cycles. Each cycle consisted of the following steps: denaturation at $95^{\circ} \mathrm{C}$ for $1 \mathrm{~min}$ (first cycle for $90 \mathrm{sec}$ ), annealing at $50^{\circ} \mathrm{C}$ for primer pairs $\mathrm{MY} 09 / 11,59^{\circ} \mathrm{C}$ for primer pairs $\mathrm{E} 7 / 16 \mathrm{~A}-\mathrm{E} 7 / 16 \mathrm{~B}$ and $55^{\circ} \mathrm{C}$ for primer pairs $\mathrm{ME} 18 \mathrm{~A} / \mathrm{B}$, and extension at $72^{\circ} \mathrm{C}$ for $1 \mathrm{~min}$. Reaction was performed in a DNA thermal cycler (Biometra). The amplification products were then analysed in $2 \%$ agarose gel with the addition of ethidium bromide in a UV transilluminator.

$I G F-I$ and IGFBP-3 levels. Serum was separated from each blood sample by centrifugation at $3000 \mathrm{x} \mathrm{g}$ for $10 \mathrm{~min}$, and used for IGF-I and IGFBP-3 level analysis. A commerciallyavailable radioimmunoassay kit (Diagnostic System Laboratories Inc.) was used to determine the serum levels of IGF-I and IGFBP-3. Analysis was performed according to the manufacturer's instructions. Standards, controls and samples were tested in duplicate. The IGF-I and IGFBP-3 serum concentrations were determined from the standard curve.

Table II. The WHO and FIGO classification of patients with tumours of the uterine cervix.

\begin{tabular}{|c|c|c|c|c|c|c|c|}
\hline \multirow[b]{2}{*}{$\begin{array}{l}\text { FIGO } \\
\text { classification }\end{array}$} & \multirow[b]{2}{*}{$\begin{array}{l}\text { No. of } \\
\text { patients }\end{array}$} & \multirow[b]{2}{*}{$\begin{array}{c}\text { WHO } \\
\text { classification }\end{array}$} & \multirow[b]{2}{*}{$\begin{array}{l}\text { No. of } \\
\text { patients }\end{array}$} & \multicolumn{4}{|c|}{ Histology of cancer } \\
\hline & & & & $\begin{array}{l}\text { Squamous cell } \\
\text { carcinoma }\end{array}$ & $\begin{array}{c}\text { No. of } \\
\text { patients }\end{array}$ & Adenocarcinoma & $\begin{array}{l}\text { No. of } \\
\text { patients }\end{array}$ \\
\hline 0 & 8 & & & & & & \\
\hline IA & 13 & G1 & 11 & Keratizing & 22 & Endocervical & 3 \\
\hline IB & 21 & $\mathrm{G} 2$ & 16 & Non-keratizing & 10 & Villoglandular & 1 \\
\hline IIA & 8 & G3 & 15 & Basaloid & 4 & $\begin{array}{l}\text { Endometroid } \\
\text { Clear cell }\end{array}$ & $\begin{array}{l}1 \\
1\end{array}$ \\
\hline Total & 50 & Total & 42 & Total & 36 & Total & 6 \\
\hline & & & & Total & & & 42 \\
\hline
\end{tabular}

Table III. Primers used for real-time PCR study of the IGF-I gene.

\begin{tabular}{llcc}
\hline & \multicolumn{1}{c}{ Primer sequence $\left(5^{\prime} \rightarrow 3^{\prime}\right)$} & Fragment length $(\mathrm{bp})$ & Annealing temperature $\left({ }^{\circ} \mathrm{C}\right)$ \\
\hline IGF-I F & GCTCTTCAGTTCGTGTGTGG & 171 & 60 \\
IGF-I R & TGACTTGGCAGGCTTGAGG & & 60 \\
GAPDH F & CAA TGA CCC CTT CAT TGA CC & 106 & 60 \\
GAPDH R & GAC AAG CTT CCC GTT CTC AG & 163 & 60 \\
Pol II F & GCAAATTCACCAAGAGAGAC & & \\
Pol II R & ATGTGACCAGGTATGATGAG & & \\
\hline
\end{tabular}


Table IV. IGF-I in the blood serum of the female study group.

\begin{tabular}{lcc}
\hline Study group & No. of cases & IGF-I (ng/ml) \\
\hline Squamous cell carcinoma HPV & 35 & 251.85 \\
Control HPV $^{+}$ & 12 & 383.58 \\
Control HPV $^{-}$ & 20 & 380.10 \\
\hline
\end{tabular}

Table V. IGFBP-3 in the blood serum of the female study group.

\begin{tabular}{lcc}
\hline Study group & No. of cases & IGFBP-3 (ng/ml) \\
\hline Squamous cell carcinoma HPV & 35 & 2316.40 \\
Control HPV $^{+}$ & 12 & 2626.29 \\
Control HPV $^{-}$ & 20 & 2616.10 \\
\hline
\end{tabular}

Immunohistochemical detection of IGF-I and IGF-IR. The reaction was conducted in paraffin blocks that were obtained from 13 infiltrating cancers and 27 precancerous lesions (L-SIL and H-SIL). Biopsies from human liver served as a positive control. The specificity of the immunoreaction was also verified for each tissue in a negative control experiment. For the immunohistochemical reaction we used corresponding sera from Sigma: IGF-I product no. I8773 in 1:10 dilution and IGF-IR product no. I7151 in 1:10 dilution. The study was conducted according to the LSAB+ System HRP method. A positive reaction in $<10 \%$ of the cells was assumed to be negative.

Real-time PCR. Cervical carcinoma, dysplastic (L-SIL and $\mathrm{H}-\mathrm{SIL}$ ) and control tissues, collected during planned gynecological operations, were immediately placed in RNAlater ${ }^{\mathrm{TM}}$ RNA Stabilization Reagent (Qiagen). Total RNA was isolated from cervical cancer tissue, dysplastic cells and healthy cells using the RNeasy Mini Kit (Qiagen) according to the manufacturer's specifications. RNA samples were treated with DNase I (Promega), and $1 \mu \mathrm{g}$ RNA (of each sample) was reverse-transcribed with SuperScript ${ }^{\mathrm{TM}}$ II RNaseH- Reverse Transcriptase (Invitrogen) into cDNA using oligo-dT primers. Real-time PCR was performed in a Light Cycler Real-Time Detection System (Roche Diagnostics) using SYBR ${ }^{\circledR}$-Green I as the detection dye. Target cDNA was quantified using the relative quantification method. The quantity of the $I G F-I$ transcripts in each sample was standardized by either glyceraldehyde-3-phosphate dehydrogenase (GAPDH) or RNA polymerase II (pol II) transcript level. Real-time PCR reactions were performed in a total volume of $20 \mu 1$. cDNA (2 $\mu 1$ ) was added to an 18- $\mu 1$ mixture of LC-FastStart DNA Master SYBR-Green I, $1.5 \mathrm{mM} \mathrm{MgCl}_{2}$ and the primers, whose sequences are listed in Table III. The primers used in real-time PCR were specific for all variants of IGF-I mRNA. Statistical analysis. The results obtained were analyzed
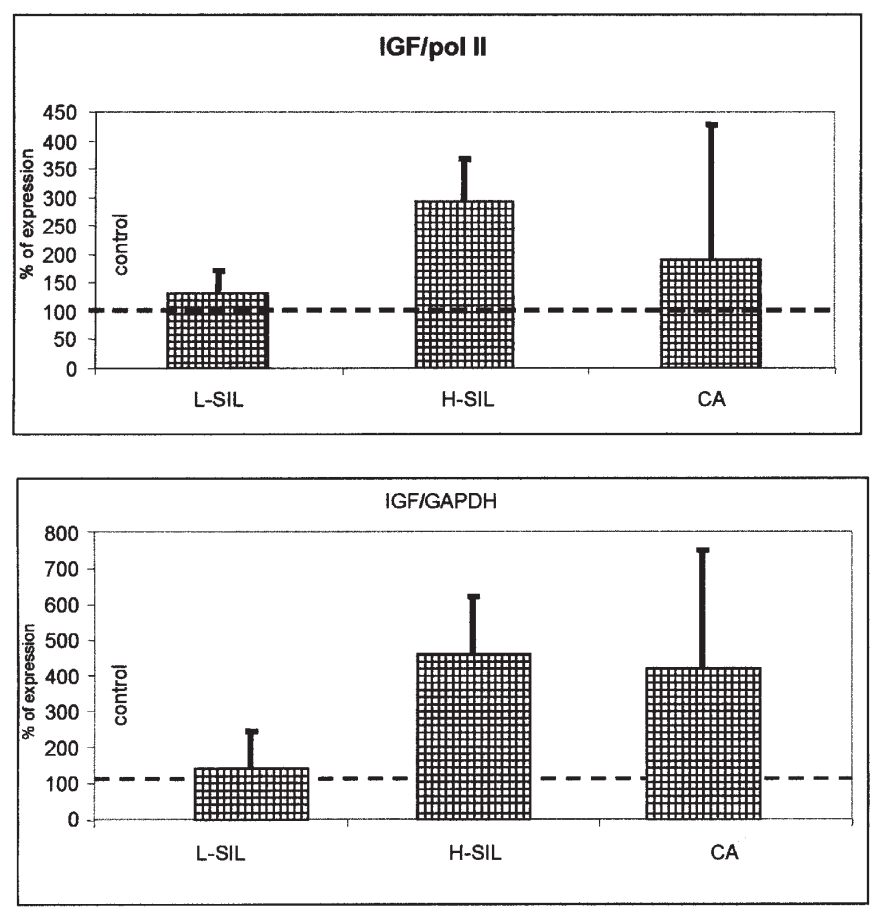

Figure 1. The expression of IGF-I in L-SIL, H-SIL, and cervical cancer tissue (CA).

statistically. Values of the analyzed parameters, due to the quotient scale of measurement, were characterized by average value, standard deviation and median, with the lower and higher quartile providing the changeability range. Due to the diagonal distribution of the studied parameters evaluated using the Shapiro-Wilk W test for the analyses of existence of differences, non-parametric tests were used. To discover differences between the compared groups, the KruskalWallis $\mathrm{H}$ test was used to compare more than two groups and the Mann-Whitney U test to compare two independent groups. The $5 \%$ error in concluding was assumed, and $\mathrm{p}<0.05$ indicated statistically significant differences.

\section{Results}

In DNA probes isolated from the cervical cells, HPV was detected in 35 of 36 patients with squamous cell carcinoma (97.2\%), 21 of 26 with H-SIL, all those with adenocarcinoma and 12 of $80(15 \%)$ of the control group women (Tables I and II). In the blood serum of the HPV-positive and HPV-negative women, the levels of IGF-I and IGFBP-3 were determined. Tables IV and V summarize the average levels of IGF-I and IGFBP-3 in the blood serum of the female study group. A statistically significant lower circulating level of IGF-I $(\mathrm{p}<0.0001)$ and IGFBP-3 $(\mathrm{p}<0.05)$ was observed in the cancer (CA) cases than in the controls. The patients had a significantly lower molar ratio of IGF-I:IGFBP-3 than the control subjects, of 0.1087 and 0.1463 , respectively. We did not find any significant differences in IGF-I and IGFBP-3 levels among control HPV-positive and HPV-negative women.

The level of IGF-I in the study tissues was determined by real-time PCR. The results are presented in Fig. 1 and in Table VI. The mRNA expression level of IGF-I increased 
Table VI. Expression of IGF-I; real-time PCR data.

A, Comparison of the IGF/GAPDH values in the control, L-SIL, H-SIL and CA groups.

\begin{tabular}{lcccc}
\hline & \multicolumn{3}{c}{ IGF/GAPDH } & Range \\
\cline { 2 - 5 } & Median & 25th percentile & 75th percentile & $0.004-1.925$ \\
Control group & 0.048 & 0.0210 & 0.127 & $0.102-0.496$ \\
L-SIL & 0.299 & 0.1020 & 0.496 & $0.046-3.187$ \\
H-SIL & 0.335 & 0.1170 & 0.034 & $0.001-10.740$ \\
CA & 0.040 & 0.0177 & 0.089
\end{tabular}

B, Comparison of the IGF/pol values in the control, L-SIL, H-SIL and CA groups.

\begin{tabular}{lrccc}
\hline & \multicolumn{3}{c}{ IGF/pol II } \\
\cline { 2 - 5 } & Median & 25th percentile & 75th percentile & Range \\
\hline Control group & 2.855 & 1.397 & 13.850 & $0.909-29.410$ \\
L-SIL & 10.101 & 7.242 & 12.960 & $7.242-12.960$ \\
H-SIL & 24.900 & 8.726 & 36.315 & $2.102-38.180$ \\
CA & 1.404 & 0.739 & 4.681 & $0.148-123.700$ \\
\hline
\end{tabular}

A

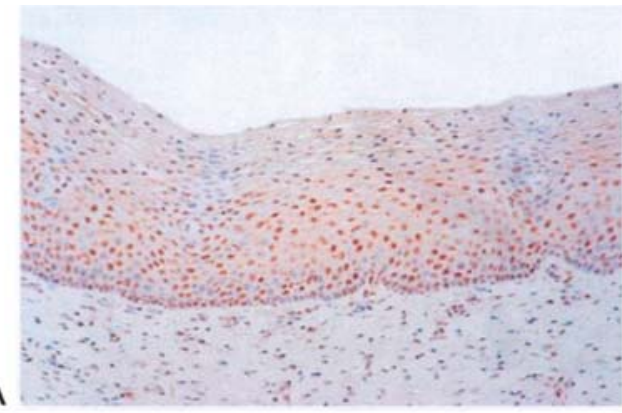

C
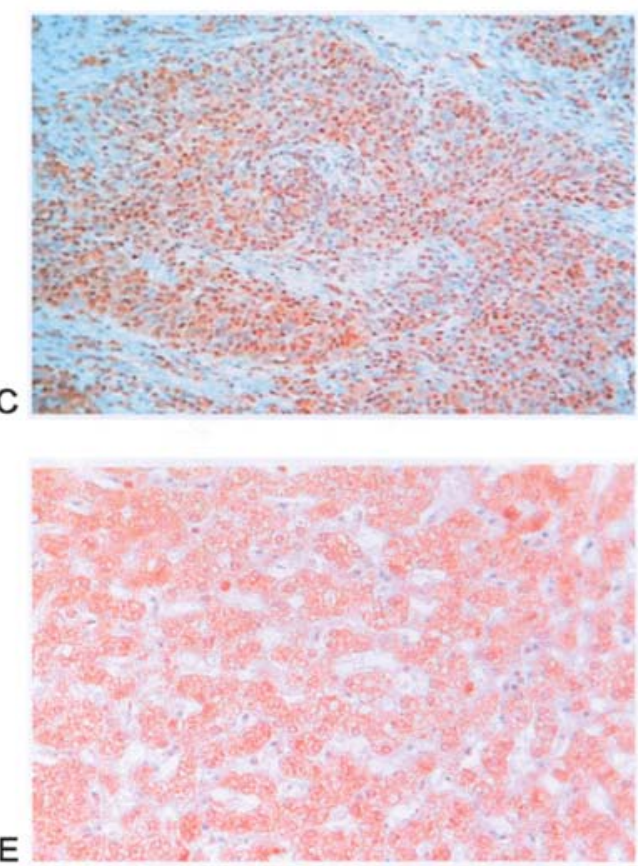

B

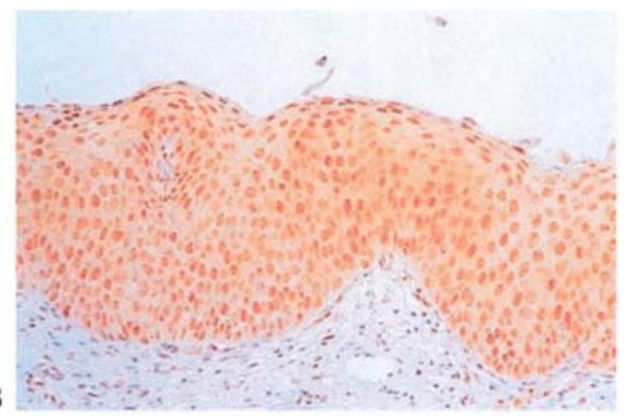

D

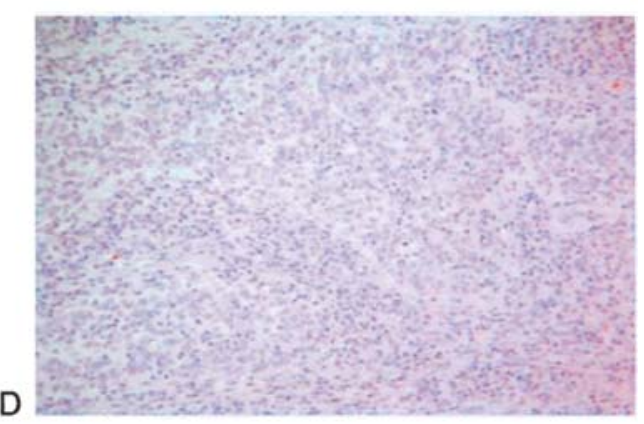

Figure 2. Immunocytochemical reaction for IGF-I in (A) normal squamous cell epithelium, (B) H-SIL, (C) squamous cell carcinoma, (D) cervical cancer tissue; negative control staining, and (E) human liver tissue; positive control staining. Magnification, x100 in A; x200 in B-E.

cells. The highest IGF/GAPDH value was found in the H-SIL group and the lowest in the CA group. On the basis of the Kruskal-Wallis H test, no statistically significant differences during cervical cancer progression, but was lower in the CA than in the H-SIL group. This indicates a potentially high proliferation resulting in clonal outgrowth of HPV16-infected 
were found in IGF-I/GAPDH between the groups compared $(\mathrm{H}=5.26 ; \mathrm{p}=0.15)$. Similarly, the highest IGF/pol II value was found in the H-SIL group and the lowest in the CA group but, on the basis of the Kruskal-Wallis $\mathrm{H}$ test, no statistically significant differences were found in IGF/pol II between the groups compared $(\mathrm{H}=5.48 ; \mathrm{p}=0.14)$.

Identification of the IGF-I protein in the cervical tissues was made by immunohistochemical analysis. The results are presented in Fig. 2. In paraepidermal epithelium from normal cervices, a positive reaction with anti-IGF-I antibody was observed in the nuclei of the basal and parabasal layer. Intermediate and superficial cells exhibited no presence of IGF-I protein (Fig. 2A). Of the 27 cases of dysplastic change of the cervix examined, there was an immunopositive reaction to IGF-I in $24(88.9 \%)$, while in three cases the reaction was negative (11.1\%) (Fig. 2B). In the H-SIL cases, the anti-IGF-I antibody showed a positive staining reaction in all layers of epithelia, including superficial cells. However, in some cases the superficial layer was negative for staining, and in L-SIL there were more stained nuclei compared to the control. In the epithelium with koilocytosis, some of the koilocytes exhibited nuclei staining with the anti-IGF-I antibody, while others remained negative. Of the ten examined planoepithelial cancers, there was expression of IGF-I in three (30\%), which was present in all structures of the cancer and was located in cancer cell nuclei (Fig. 2C). Two of the cancers exhibited intermediate differentiation (G2) and one was highly-differentiated (G1), with a staging of IB. The expression of IGF-I was not detected in four cancers $(40 \%)$, two of them welldifferentiated (G1) and two with intermediate differentiation (G2), with a staging of IB. In the remaining three cancers, in which the staging was slightly higher than IA, there was a strong staining reaction in deeper infiltrating cancer cells.

In the control paraepidermal epithelium of cervices, a positive staining reaction with the anti-IGF-IR antibody was observed in only cell membranes of the basal cell layer, and rarely in the parabasal. In invasive cancers, the most intensive staining was observed in the cell membranes of the cases in which there was pronounced expression of IGF-I. In the remaining cancers, the reaction was focal with weak expression or no reaction present.

\section{Discussion}

Pap smear and HPV identification are of limited value as screening tests for cervical cancer because not all women with an abnormal Pap smear or positive HPV test progress to cervical cancer $(1,16)$. A marker that aids in the identification of women who are at risk of developing cervical cancer would therefore be useful for prevention. Growth factors, such as IGF-I, are thought to be agents that stimulate proliferation and enhance the possibility of malignant transformation in HPV-positive cells. IGF-I is involved in both human development and the maintenance of the normal functions and homeostasis of most cells of the body, as well as performing the classic role of endocrine hormone. IGF-I regulates a wide range of biological functions, such as cell proliferation, differentiation and apoptosis through paracrine and autocrine mechanisms. Over $75 \%$ of IGF-I in circulation is produced in the liver. IGF-I interacts with its cell membrane receptor IGF-IR to influence various cellular activities, such as cell transit from the G1 to S phase, by stimulating the mitogenactivated protein kinase signal transduction pathway, which increases the production of cyclin D1. IGF-I also contributes to the suppression of apoptosis and increased cell growth by enhancing the production of BCL proteins and inhibiting the production of BAX proteins $(5,17,18)$. IGFBPs play a role in controlling the interaction between IGF-I and IGF-IR by binding to IGF-I, thereby blocking their binding to IGF-IR. An association between IGF-I levels and invasive cancer risk has been demonstrated in numerous studies for a variety of epithelial cells (prostate, lung, breast and colorectal) (12). Little is known about the role of IGF-I in cervical cancer development. Ayabe et al (19) found no significant association between the serum levels of IGF-I and the risk of cancer. Wu et al (14) demonstrated a relationship between the serum level of IGF-I and precancerous SILs. Individuals with either high- or lowgrade SILs exhibited significantly higher serum levels of IGF-I, IGFBP-3 and IGF-I:IGFBP-3 molar ratio than control subjects. However, women with high-grade lesions did not exhibit higher IGF-I levels than women with low-grade ones (14).

Our study indicated a statistically significant lower circulating level of IGF-I $(\mathrm{p}<0.001)$ and IGFBP-3 $(\mathrm{p}<0.05)$ in CA cases than in controls. We did not find any significant differences in IGF-I and IGFBP-3 levels between HPV-positive and HPV-negative control women.

The association between lower serum levels of IGF-I and IGFBP-3, IGF-I:IGFBP-3 molar ratio and cervical cancer was observed by Serrano et al (15), who suggested that circulating levels of IGF-I and IGFBP-3 can be affected by the malignant disease itself, and that lower levels of IGF-I in cancer might be more a consequence of the malignant disease than of an associated risk factor. In addition to the liver, many other organs produce IGF-I, which has a lower affinity for IGFBPs, representing an autocrine and paracrine form of IGF-I. By reverse transcription followed by real-time PCR, IGF-I mRNA was detected in normal cervical cells, CIN and cervical cancer. The IGF-I mRNA level was higher in L-SIL and H-SIL and in cervical carcinoma than in the control cells. Our immunohistochemical study showed that IGF-I and IGF-IR proteins were also present in the normal cervical epithelial tissue and were more abundant in L-SIL/H-SIL and CA planoepithelial cells than in control cells. Many previous studies on IGF-I have focused their attention on the cell surface. In this study, an immunopositive reaction for IGF-IR was present in cell membranes of epithelial neoplasia (L-SIL/H-SIL) and in the cervical cancer cells that stained positively for IGF-I. However, IGF-I was also observed in the nuclei of the reproductive layer of paraepidermal epithelium, in intraepithelial neoplasia (L-SIL/ H-SIL) and in cervical cancer cells. The presence of IGF-I at a nuclear localization suggests that IGF-I may also have intranuclear activity, for example in gene regulation. The IGF-I gene is alternatively spliced, generating a number of protein isoforms which differ in the length of the amino-terminal leader (signal peptide) and in the structure of the so-called extension peptide (E-Peptid) on the C terminal end (20).

Functional differences between IGF-I mRNAs and regulatory mechanisms for the alternative splicing of IGF-I mRNA are as yet unknown. Ohtsuki et al (21) indicated that the expression of IGF-I mRNA variants is regulated in an organ- 
specific and age-dependent manner, and that estrogen is involved in changes in IGF-I mRNA variant expression. Therefore, high IGF-I expression may be due to high local estrogen levels (22). In the regulation of the splicing of IGF-I, exon 5 alternatively collaborates with purine-rich enhancer and CUG-binding protein SF2/ASF and hNRNP H, which are part of spliceosomes (23). Tan et al (24) found one isoform of human IGF-I (IGF-IB) that localized to the nucleus and mapped C-terminal domains of the exon 5 requirement for such localization. This isoform is probably present in the nucleus of cervical cells. However, further studies are needed to confirm this suggestion. At present, there is a lack of experimental data on the functional significance of IGF-I isoforms. Localization of IGF-I in the nucleus shows that IGF-I in basal keratinocytes could have a more complex mechanism of action than that previously envisaged in the control of epidermal growth and differentiation. The different IGF-I peptides might modulate the actions, stability or bioavailability of IGF-I, or might have independent activity. The general increase in IGF-I mRNA during carcinogenesis and immunohistochemistry indicates that it may be functionally important during this process. The ectocervical epithelium is also the target of oncogenic HPV forms, which are key etiological agents in the development of cervical carcinoma. The role of HPV in the expression and splicing of IGF-I pre-mRNA is unknown. The data of McPhillips et al (25) suggest that E2 viral HPV16 protein, which is essential for the life cycle of the virus, is also responsible for controlling the expression of the protein SF2/ASF. The level and phosphorylation of SF2/ASF are upregulated with epithelial differentiation, as in subcellular distribution, in HPV16-infected epithelial cells. Through an increase in the level of E2, the levels of some IGF-I isoforms (in L-SIL/H-SIL) are also increased. It is also possible that other viral proteins are involved in regulating the expression and activity of SF2/ASF in IGF-I mRNA splicing (26).

The loss of the E2 gene can have a negative effect on cell growth and usually accompanies the development of invasive cervical cancer. In human cervical cancer cells, the E2 gene is usually disrupted, and HPV DNA integrated with host DNA expresses the HPV E6 and E7 oncogenes, which exert their proliferative effect by binding to and inactivating the tumor suppressor proteins p53 and Rb (27-29). The data of Baege et al (30) also indicates that E6/E7 immortalized cervical cells secrete IGFBP-3 and increase mitogenic sensitivity to IGF-I. IGFBP-3 can be inhibited by E7, which binds to IGFBP-3 and triggers its proteolytic cleavage. This is associated with an increase in IGF-I levels (31). Berger et al (32) indicated that, at early passages, cervical cells transduced with HPV16/18 E6/E7 genes demonstrated increased expression of the cell cycleregulated gene $\mathrm{CDC} 2$ ubiquitin carrier E2C. At later passages, these same cells exhibited increased IGFBP-3 mRNA, both secreted and intracellular protein, with mRNA levels increasing 85 -fold. This suggests that E6/E7 expression alone is not sufficient to induce IGFBP-3, and that additional changes associated with immortalization are likely required. Our results show that the autocrine effects of IGF-I on cervical cell proliferation, and their interplay with other cellular and viral factors, may have an important role in cervical cancer development. Further studies are needed to examine the exact contribution of IGF-I to this process.

\section{References}

1. Zur Hausen H: Papillomaviruses causing cancer: evasion from host-cell control in early events in carcinogenesis. J Natl Cancer Inst 92: 690-698, 2000.

2. Rotwein P, Pollock KM, Didier DK and Krivi GG: Organization and sequence of the human insulin-like growth factor I gene. Alternative RNA processing produces two insulin-like growth factor I precursor peptides. J Biol Chem 15: 4828-4832, 1986.

3. Kamai Y, Mikawa S, Endo K, Sakai H and Komano T: Regulation of insulin-like growth factor-I expression in mouse preadipocyte Ob1771. J Biol Chem 271: 9883-9886, 1996.

4. Shavlakadze, Winn N, Rosenthal N and Grounds MD: Reconciling data from transgenic mice that overexpress IGF-1 specifically in skeletal muscle. Growth Horm IGF Res 15: 4-18, 2005.

5. Jones JI and Clemmons DR: Insulin-like growth factors and their binding proteins: biological actions. Endocr Rev 16: 3-34, 1995.

6. LeRoith D, Werner H, Beitner-Johnson D and Roberts CT Jr: Molecular and cellular aspects of the insulin-like growth factor I receptor. Endocr Rev 16: 143-163, 1995.

7. Chan JM, Stampfer MJ, Giovannucci E, et al: Plasma insulinlike growth factor-I and prostate cancer risk: a prospective study. Science 279: 563-566, 1998.

8. Yu H, Spitz MR, Mistry J, Gu J, Hong WK and Wu X: Plasma levels of insulin-like growth factor-I and lung cancer risk: a casecontrol analysis. J Natl Cancer Inst 91: 151-156, 1999.

9. Wu X, Yu H, Amos CI, Hong WK and Spitz MR: Joint effect of insulin-like growth factors and mutagen sensitivity in lung cancer risk. J Natl Cancer Inst 92: 737-743, 2000.

10. Hankinson SE, Wilett WC, Colditz GA, et al: Circulating concentrations of insulin-like growth factor-I and risk of breast cancer. Lancet 351: 1393-1396, 1998.

11. Kaaks R, Toniolo P, Akhmedkhanov A, et al: Serum C-peptide, insulin-like growth factor (IGF)-I, IGF-binding proteins, and colorectal cancer risk in women. J Natl Cancer Inst 92: 1592-1600, 2000.

12. Pollak M: Insulin-like growth factor physiology and cancer risk. Eur J Cancer 36: 1224-1228, 2000.

13. Wu X, Zhao H, Do KA, Johnson MM, Dong Q, Hong WK and Spitz MR: Serum levels of insulin growth factor (IGF-I) and IGFbinding protein predict risk of second primary tumors in patients with head and neck cancer. Clin Cancer Res 10: 3988-3995, 2004.

14. Wu X, Tortolero-Luna G, Zhao H, Phatak D, Spitz MR and Follen M: Serum levels of insulin-like growth factor I and risk of squamous intraepithelial lesions of the cervix. Clin Cancer Res 9: 3356-3361, 2003.

15. Serrano ML, Romero A, Cendales R, Sanchez-Gomez M and Bravo MM: Serum levels of insulin-like growth factor-I and II and insulin-like growth factor binding protein 3 in women with squamous intraepithelial lesions and cervical cancer. Biomedica 26: 258-268, 2006.

16. Goldie SJ: Health economy and cervical cancer prevention: a global perspective. Virus Res 89: 301-309, 2002.

17. Wang L, Ma W, Markovich R, Lee WL and Wang PH: Insulinlike growth factor I modulates induction of apoptotic signaling in H9C2 cardiac muscle cells. Endocrinology 139: 1354-1360, 1998.

18. Yu H and Rohan T: Role of the insulin-like growth factor family in cancer development and progression. J Natl Cancer Inst 29: 1472-1481, 2000.

19. Ayabe T, Tsutsumi O, Sahai H, Yoshikawa H, Yano T, Kurimoto $\mathrm{F}$ and Taketani $\mathrm{Y}$ : Increased circulating levels of insulin-like growth factor bindings protein in postmenopausal women with endometrial cancer. Endocr J 44: 419-424, 1997.

20. Barton ER: The ABC soft IGF-I isoforms: impact on muscle hypertrophy and implications for repair. Appl Physiol Nutr Metab 31: 791-797, 2006.

21. Ohtsuki T, Otsuki M, Murakami Y, et al: Organ-specific and age-dependent expression of insulin-like growth factor-I (IGF-I) mRNA variants: IGF-IA and IGF-IB mRNAs in the mouse. Zoolog Sci 22: 1011-1021, 2005.

22. Ekman-Ordeberg G, Stjernholm Y, Wang H, Stygar D and Sahlin L: Endocrine regulation of cervical ripening in humans potential role for gonadal steroids and insulin-like growth factor-I. Steroids 68: 837-847, 2003

23. Smith PJ, Spurreli EL, Coakley J, Hinds CJ, Ross RJ, Krainer AR and Chew SL: An exonic splicing enhancer in human IGF-I pre-mRNA mediates recognition of alternative exon 5 by the serine-arginine protein splicing factor2/alternative splicing factor. Endocrinology 143: 146-154, 2007. 
24. Tan DS, Cook A and Chew SL: Nucleolar localization of an isoform of the IGF-I precursor. BMC Cell Biol 3: 17, 2002.

25. McPhillips MG, Veerapraditsin T, Cumming SA, et al: SF2/ASF binds the human papillomavirus type 16 late RNA control element and is regulated during differentiation of virus-infected epithelial cells. J Virol 78: 10598-10605, 2004.

26. Ham J, Dostatni N, Gauthier JM and Yaniv M: The papillomavirus E2 protein: a factor with many talents. Trends Biochem Sci 16: 440-444, 1991.

27. Doorbar J: The papillomavirus life cycle. J Clin Virol 32 (Suppl. 1): S7-S15, 2005.

28. Huibregtse JM, Scheffner M and Howley PM: Cloning and expression of the cDNA for E6-AP, a protein that mediates the interaction of the human papillomavirus E6 oncoprotein with p53. Mol Cell Biol 13: 775-784, 1993.

29. Jewers RJ, Hildebrandt P, Ludow JW, Kell B and McCance DJ: Regions of human papillomavirus type 16 E7 oncoprotein required for immortalization of human keratinocytes. J Virol 66: 1329-1335, 1992.
30. Baege AC, Disbrow GL and Schlegel R: IGFBP-3, a marker of cellular senescence, is overexpressed in human papillomavirusimmortalized cervical cells and enhances IGF-I-induced mitogenesis. J Virol 78: 5720-5727, 2004.

31. Mannhardt B, Weinzimer SA, Wagner M, Fiedler M, Cohen P, Jansen-Durr P and Zwerschke W: Human papillomavirus type 16E7 oncoprotein binds and inactivates growth-inhibitory insulinlike growth factor binding protein 3. Mol Cell Biol 20: 6483-6495, 2000 .

32. Berger AJ, Baege A, Guillemette T, et al: Insulin-like growth factor-binding protein 3 expression increases during immortalization of cervical keratinocytes by human papillomavirus type 16 E6 and E7 proteins. Am J Pathol 161: 603-610, 2002.

33. Tavassoli FA and Deville P (eds): IARC Pathology and Genetics of Tumours of the Breast and Female Genital Organs. IARC Press, Lyon, 2003. 